
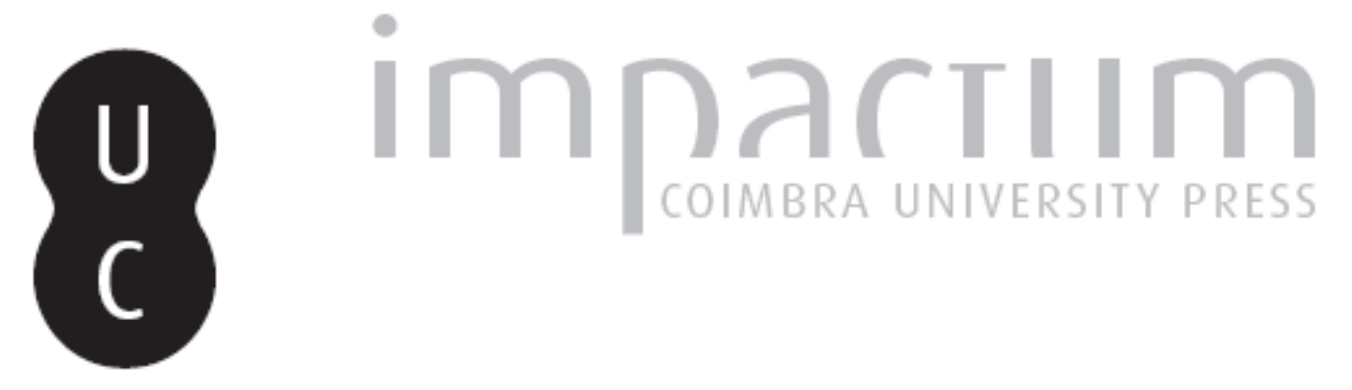

\title{
Acerca de Silva Dias no seu centenário: evocação em jeito de história e de memória Autor(es): $\quad$ Torgal, Luís Reis
}

Publicado por: Imprensa da Universidade de Coimbra

URL persistente:

URI:http://hdl.handle.net/10316.2/40209

DOI:

DOI:https://doi.org/10.14195/2183-8925_34_3

Accessed : $\quad$ 26-Apr-2023 12:20:26

A navegação consulta e descarregamento dos títulos inseridos nas Bibliotecas Digitais UC Digitalis, UC Pombalina e UC Impactum, pressupõem a aceitação plena e sem reservas dos Termos e Condições de Uso destas Bibliotecas Digitais, disponíveis em https://digitalis.uc.pt/pt-pt/termos.

Conforme exposto nos referidos Termos e Condições de Uso, o descarregamento de títulos de acesso restrito requer uma licença válida de autorização devendo o utilizador aceder ao(s) documento(s) a partir de um endereço de IP da instituição detentora da supramencionada licença.

Ao utilizador é apenas permitido o descarregamento para uso pessoal, pelo que o emprego do(s) título(s) descarregado(s) para outro fim, designadamente comercial, carece de autorização do respetivo autor ou editor da obra.

Na medida em que todas as obras da UC Digitalis se encontram protegidas pelo Código do Direito de Autor e Direitos Conexos e demais legislação aplicável, toda a cópia, parcial ou total, deste documento, nos casos em que é legalmente admitida, deverá conter ou fazer-se acompanhar por este aviso.

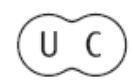



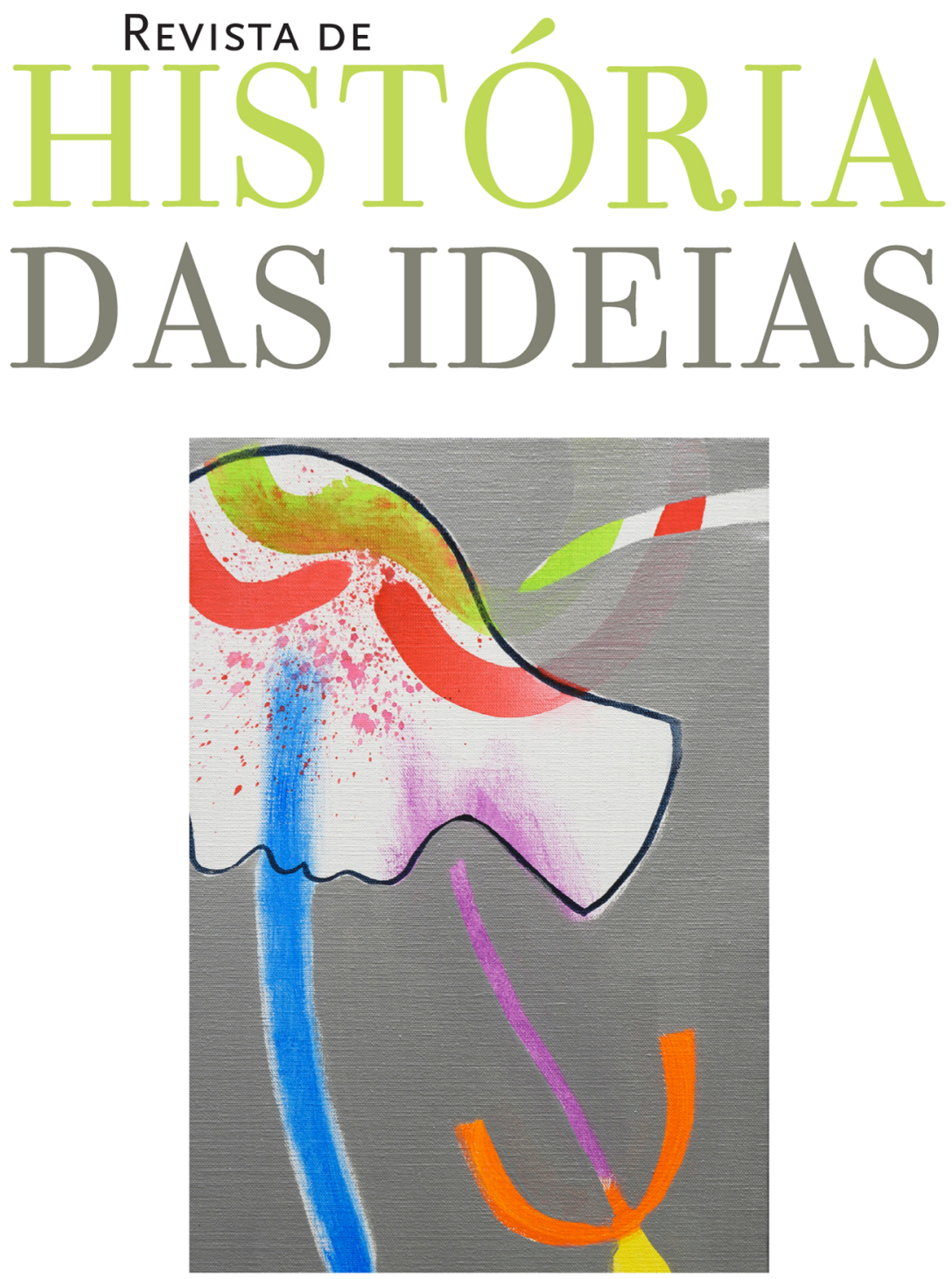

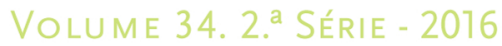




\section{ACERCA DE SILVA DIAS NO SEU CENTENÁRIO EVOCAÇÃO EM JEITO DE HISTÓRIA E DE MEMÓRIA EVOKING SILVA DIAS ON HIS CENTENARY: HISTORY AND MEMORY}

LUís REIS TORGAL*

lreistorgal@gmail.com

Faculdade de Letras da UC/CEIS20

Texto recebido em / Text submitted on: 30/06/2016

Texto aprovado em / Text approved on: 19/07/2016

\section{Resumo:}

Evocar um autor pode supor uma análise histórica objetiva e um recurso à memória, ou seja, ao testemunho pessoal do autor. Foi isso que se pretendeu fazer, ao escrever este artigo sobre José Sebastião da Silva Dias. Assim, analisou-se Silva Dias como ideólogo, que foi passando de uma perspetiva católica e integralista, com um lastro social, para uma perspetiva socialista democrática. Mas também se tentou mostrar que Silva Dias chegou a essa ideologia através de uma análise objetiva da História, em que se interligava o conhecimento do documento com a reflexão filosófica. Acima de tudo, como modernista e como contemporaneísta

"Professor catedrático aposentado da Faculdade de Letras da Universidade de Coimbra e fundador e investigador do Centro de Estudos Interdisciplinares do Século XX da UC (CEIS20). O autor - sem pretender defender qualquer sistema - não escreve de acordo com o novo Acordo Ortográfico. Todavia, perante as exigências institucionais, aceitou que este artigo fosse publicado em função da ortografia agora regulamentada oficialmente. 
(neste caso mais como orientador de investigação) deve-se-lhe uma «escola» ou «escolas». No fundo renovou a historiografia, lançando as bases, desde os anos de 1960, dos estudos científicos da História Contemporânea.

\title{
Palavras-chave:
}

Silva Dias, Ideologia católica, Integralismo, Historiografia, História Moderna e Contemporânea.

\begin{abstract}
:
To evoke an author may involve an objective historical analysis and the recourse to memory, i.e. to the author's personal testimony. Such was our intention by writing the present paper on José Sebastião da Silva Dias. Therefore, we studied Silva Dias as an ideologist, who shifted from Catholicism and integralism, with a social ballast, to a democratic socialist outlook. We have also tried to highlight that Silva Dias arrived at that ideology through an objective analysis of History, connecting the knowledge of the document to philosophical thinking. Above all, as a modernist and contemporanist (in this case mostly as a research supervisor) we owe him a «school « or «schools». Ultimately, he renewed historiography, laying the grounds, since the 1960s, of scientific Contemporary History Studies.
\end{abstract}

\section{Keywords:}

Silva Dias, Catholic Ideology, «Integralismo», Historiography, Modern and Contemporary History.

\section{Silva Dias: morte, nascimento e seu centenário}

José Sebastião da Silva Dias nasceu em Arcos de Valdevez no dia 9 de fevereiro de 1916, vindo a falecer em Lisboa a 23 de novembro de $1994^{(1)}$. Encontrava-me eu em Paris e, infelizmente, não pude estar presente no seu funeral. Mas colaborei, assim como outros colegas, na homenagem que antes lhe foi prestada, por altura da sua jubilação, em dois números da Revista de História das Ideias ${ }^{(2)}$, enquanto era diretor dessa

(1) Ver In Memoriam, Biblos, LXX (1994), p. 635-638, e Revista de História das Ideias, 16 (1994), p. 577-580. Ver também, do autor: Dicionário de Historiadores Portugueses (Coord. Sérgio Campos Matos), http:/ / dichp.bnportugal.pt/historiadores/historiadores_silva_dias.htm

(2) Revista de História das Ideias, 8 e 9, «O Sagrado e o Profano» (1986 e 1987). A revista teve, no . $^{\circ}$ 9, 2 vols. 
publicação por ele fundada, e em uma sessão realizada na Faculdade de Letras da Universidade de Coimbra, no dia 19 de setembro de 1997, onde fundou, primeiro, o Seminário de Cultura Portuguesa e, depois, em 1976, o Instituto de História e Teoria das Ideias, de onde sairia, em 1978, o primeiro número da referida revista.

Nessa sessão fez-se uma exposição das suas obras, na sala onde durante anos funcionou o Instituto ${ }^{(3)}$, e foi afixado na porta o seu nome: «Sala Silva Dias». Não recordo as palavras que, espontaneamente e do coração, então proferi, mas posso ou podemos lembrar-nos, através da sua publicação, da interessante intervenção do nosso colega António Resende de Oliveira, que coordenou esse número da revista, o qual, ao elogiar o seu trabalho, falou da «institucionalização da História da Cultura como saber histórico» por Silva Dias, alterando o trajeto que fundamentalmente vinha a percorrer graças ao trabalho de investigadores formados na área da literatura, como António José Saraiva (ao qual se poderia juntar Hernâni Cidade, que o antecedeu $)^{(4)}$.

Idêntico tipo de celebração foi realizado pelo Centro de História da Cultura, que Silva Dias veio a criar na Universidade Nova de Lisboa, para onde se transferiu em 1979-1980, como sempre cheio de ideais de transformação que lhe provocavam grandes desilusões, e onde viria a criar uma nova revista, Cultura. História e Filosofia. Também esta publicação lhe dedicou um volume ${ }^{(5)}$.

Mais tarde, em dezembro de 2004, foi adquirida a maior parte da sua biblioteca. Finalmente, passados mais de dez anos a Direção da Faculdade de Letras, de acordo com o desejo dos seus discípulos e era a vontade da Dra . Graça Silva Dias, propõe-se criar na "Sala Silva Dias" um núcleo com as suas obras. Espero também que se possa vir a publicar um catálogo dos seus livros, a fim de se poder estudar a composição da sua livraria, com todo o seu significado ou significados

(3) Ver «Para uma bibliografia de J. S. da Silva Dias», organizada por Maria do Rosário Azenha, Revista de História das Ideias, 8 (1986), p. 11-23. Nova edição: Subsídios para uma bibliografia de J. S. da Silva Dias, Coimbra, Faculdade de Letras, 1987. Pode ver-se, em versão atualizada: http:/ / www.ci.uc.pt/ihti/portugues/ihti/silva_dias.html.

(4) Ver «José Sebastião da Silva Dias. Institucionalização da História da Cultura como saber histórico», Revista de História das Ideias, 19 (1998), p. 595-599. O tema deste número, coordenado por António Resende de Oliveira, foi «A cultura da Nobreza».

(5) Cultura. História, Filosofia, VI (1987). 
Em tempo mais recente, 2014, foi dado o nome de Silva Dias a outra sala da cidade, desta vez na Casa Municipal da Cultura de Coimbra. Tal responsabilidade coube à Comissão de Toponímia, de que fazia parte uma sua discípula, Isabel Vargues. Seria melhor (a meu ver) ter-lhe sido atribuído o nome de uma rua (como sucedeu na sua terra natal, Arcos de Valdevez, e como aconteceu com outros professores e personalidades várias que se distinguiram em Coimbra), mas a verdade é que Silva Dias foi também, e principalmente, como se vê pela sua extensa obra, um homem de cultura. Todavia, o Município deveria ter melhor justificado esta opção e apresentado a sua obra, numa sessão pública realizada para o efeito, o que julgo não ter sucedido.

Obviamente, portanto, não poderia agora deixar de colaborar, com um texto, no centenário do seu nascimento (ocorrido exatamente no passado dia 9 de fevereiro de 2016), que foi recordado graças ao nosso colega Manuel Augusto Rodrigues, a quem se deve a Introdução e Coordenação da reedição, em $2006^{(6)}$, da primeira grande obra de História de Silva Dias, publicada na Biblos, em $1952^{(7)}$. Nessa altura a revista da Faculdade de Letras de Coimbra publicava grandes estudos, tais como teses de doutoramento, o que não era o caso ${ }^{(8)}$.

Tendo sido praticamente o seu primeiro discípulo ${ }^{(9)}$, aqui estou, com grande gosto - e só não digo com saudade, porque sou um pouco avesso a esse sentimento que dizem ser bem português - a «homenageá-lo», ao meu jeito de tentativa de análise objetiva, pois como escrevi, num artigo sobre José Luciano de Castro, «a História não presta homenagens». Entendo a vida e a história como uma espécie de espiral - daí a sua aparência por

(6) Portugal e a cultura europeia do século XVI a XVIII, Porto, Campo das Letras, 2006.

(7) Biblos, 28 (1952), p. 20-498.

(8) Silva Dias, que depois percorreu a carreira normal da docência, não realizou propriamente provas de doutoramento, tendo-lhe sido concedido - de acordo com a legislação em vigor - pelo então Conselho Escolar, em 5 de maio de 1961, devido às obras até então publicadas, o grau de doutor em Filosofia, cujas insígnias recebeu em ato solene no dia 20 de março de 1966 (José Sebastião da Silva Dias, Curriculum Vitae, 1969, p. 9).

(9) Verdadeiramente o primeiro assistente ligado ao Professor Silva Dias foi o meu colega Amândio Coxito. Licenciado e depois doutorado em Filosofia, foi docente de História da Filosofia em Portugal. Na área propriamente de História da Cultura, ministrando as aulas práticas de História da Cultura Moderna e tendo feito parte da criação do seu primeiro núcleo, o Seminário de Cultura Portuguesa, fui eu o primeiro assistente ( «Segundo Assistente», de acordo com a legislação do tempo, denominação logo depois alterada), tendo ingressado na Faculdade de Letras, na área das disciplinas «não agrupadas» e ligado à Filosofia, tomando posse em 21 de março de 1970. 
vezes de circularidade -, em que nunca se volta ao mesmo ponto e em que por isso sentimentos de saudade e de fado são apenas afetos que nos parecem fazer voltar atrás ou ir para a frente com um destino marcado. Silva Dias criou uma «escola», ou várias, e acima de tudo o que devemos salientar é o futuro das Ciências Sociais, ou sobretudo da História, a que se dedicou, como cientista, em Coimbra e em Lisboa ou em Lisboa e em Coimbra, conforme a cronologia que se queira usar, da sua investigação pessoal ou da sua integração e criação institucional.

\section{Silva Dias, filósofo ou ideólogo católico?}

O meu colega Amadeu Carvalho Homem, que há muito possui um blog, nas suas crónicas, dedicou uma, em 10 de outubro de 2007, a Silva $\operatorname{Dias}^{(10)}$. Contava ele - com alguma ironia, humor e o sentido polémico que lhe é característico - que um dia perguntou a Silva Dias como se fazia investigação histórica (curiosamente um antigo aluno que trabalha num Município acabou de me fazer idêntica pergunta). O Mestre respondeulhe, com uma certa graça e aparente simplicidade, que investigar era como nadar: começa por se esbracejar e aprende-se a nadar ou se se afoga, o que significa que não se tem tendência para a investigação. E rematava Carvalho Homem:

Hoje um desses pseudo-pedagogos de plástico talvez tivesse respondido ao meu aflito inquérito com as seguintes considerações: - Investigar? [...] Vá à Internet, meu amigo. Vá lá e compre uma investigação já feita [...]. Como me orgulho de ter sido discípulo do saudosíssimo Doutor José Sebastião da Silva Dias! [...].

Além do caráter sugestivo desta homenagem, cito este texto porque fui à Internet, ao que hoje já se chama ironicamente «Dr. Google», ou melhor, à Wikipédia, ver o que se dizia de Silva Dias. Devo dizer que o texto está suficientemente correto, pois baseia-se na síntese biográfica e no levantamento das obras do autor realizados por Maria do Rosário Azenha, que o secretariou em Coimbra, mas inicia-se com uma afirmação discutível. Diz ter sido, além de professor na Faculdade de Letras da

(10) http:/ / livre-e-humano.blogspot.pt/2007/10/homenagem-j-s-da-silva-dias.html 
Universidade de Coimbra e na Faculdade de Ciências Sociais e Humanas da Universidade Nova de Lisboa, «um filósofo».

Claro que a palavra «filósofo» pode ter várias aceções, até um significado pejorativo (o que não é, obviamente, o caso): pretendeuse porventura salientar aqui que Silva Dias terá refletido sobre vários temas como pensador ou ensaísta, sem propriamente afirmar que se trata de um intelectual que criou - o que não sucedeu - um sistema de pensamento, um «sistema filosófico». Na verdade, olhando à primeira fase de Silva Dias em Coimbra e em Lisboa, será que foi verdadeiramente «um filósofo» ou foi antes um ideólogo? Com certeza que abordou temas vários, de ordem religiosa, política, social e cultural, com profundidade, mas o que vem ao de cimo é, sem dúvida, a sua ideologia católica de tipo (por assim dizer) «integralista moderno», que acabou por se encontrar, no círculo de influências do Estado Novo, com outros pensadores, sem a ele expressamente se ligar.

Presidente do CADC (Centro Académico de Democracia Cristã), em 1939-1940 e em 1940-1941, ano em que se formou em Direito e em que se deu o primeiro movimento académico que começou a reclamar contra o aumento das propinas ${ }^{(11)}$, escreveu, na revista Estudos (a cujo corpo redatorial pertenceu), sobre temas gerais de reflexão espiritual ou de interpretação dos grandes acontecimentos que então se passavam no mundo, como o Anschluss ou a Guerra Civil de Espanha, ou acerca das ideias de iberismo ou de "génio da raça».

Quanto à «anexação» da Áustria pelo Führer (13 de março de 1938), entende-a como a defesa da etnia e da cultura alemãs (que se vinha a processar muito antes) - a qual Silva Dias criticava (de resto o nazismo esteve sempre na mira dos seus ataques, como todos os totalitarismos) -, em luta contra a «Internacional», mas desta vez contra a «Internacional Romana», que Hitler entendia, erradamente, como aliada da outra Internacional, a Comunista ${ }^{(12)}$. Por outro lado, no meio da violência bélica que se verificava em Espanha, Silva Dias só se

(11) Decreto-lei n. ${ }^{\circ} 31.658,21$ de novembro de 1941. Alguns integralistas e católicos, como Henrique Barrilaro Ruas, que pertenceu à direção do CADC, tomaram também posição contra esse decreto, conforme Barrilaro veio a testemunhar (Sobre a questão académica, Coimbra, Gráfica de Coimbra, 1945, p. 3-4).

(12) «Timeo danaos», Estudos, 15 (170-171) (1938), p. 521-524. A expressão «timeo danaos» faz parte de uma frase mais completa da Eneida de Virgílio (II, 49), «timeo danaos et dona ferentes», querendo significar «temo os gregos, mesmo quando oferecem presentes», 
mostra como parcialmente defensor do franquismo, tendo em conta a sua batalha contra a ideologia comunista. Não recusa a realidade dos «crimes que se têm cometido na zona franquista», inclusivamente contra padres e freiras - «O crime deve sempre ser reprovado, venha donde vier», sublinha -, mas aceita, em nome do Catolicismo, que os seus prosélitos «não devem hostilizar a situação franquista». E conclui: «Por isso, a posição dos católicos é ao lado de Franco. Apenas auguramos que o Caudilho, ganhando a guerra, não perca a paz» ${ }^{(13)}$. A Espanha era, pois, para o jovem Silva Dias - de alguma forma como fora para António Sardinha e os integralistas originários -, a sua «segunda pátria», ou seja, significava, com Portugal, a ideia de Cristandade, «a alma ibérica, nervo da nossa peregrinação multissecular através da História», o «império» cultural que representava a «hispanidade», o «génio da Raça», não numa perspetiva temporal e racista, mas como um sentimento espiritual ${ }^{(14)}$.

Silva Dias alinhava então, portanto, numa conceção, pode dizer-se (como já afirmei), «integralista», mesmo quando discutia temas como o século XVII - recorde-se como era polémica desde há muito a questão do Seiscentismo, sobretudo após a publicação da tese de Manuel Múrias sobre o tema, nos inícios dos anos $20^{(15)}$, que encontrara a oposição de António Sérgio e de outros intelectuais democratas -, que trazia para a frente a discussão do papel da Inquisição e da Censura como eventuais causadoras do atraso da cultura portuguesa. Num artigo de 1940 sobre o tema, Silva Dias defendia mesmo a tese de Alfredo Pimenta de que ambas, ao contrário do que se dizia, haviam sido de grande benevolência, só não o sendo quando se pretendia «corromper» a teologia, «envenenar as almas» ${ }^{(16)}$, rematando desta forma:

Por tudo isto, podemos concluir que a Inquisição e a Censura, se uma vez ou outra, pelos excessos e pelos abusos dos homens, foram perniciosas

referindo-se ao caso do famoso cavalo de Tróia. Ou seja, significa que devemos temer os inimigos mesmo quando parecem defender uma boa causa.

(13) «A propósito da Guerra de Espanha», Estudos, 16 (175) (1939), p. 140-145.

(14) «El ibérico solar», Estudos, 17 (190) (1940), p. 263-380.

(15) O Seiscentismo em Portugal, Lisboa, 1923.

(16) D. João III, Porto, Livraria Tavares Martins, 1936, p. 159 ss., e Elementos de História de Portugal, Lisboa, Empresa Nacional de Publicidade, 1934, p. 242-252. Silva Dias cita a p. 221 do texto sobre D. João III. 
para a inteligência, - duma maneira geral é débil o seu contributo para o aviltamento intelectual do século XVII, se é que existiu(17).

Na sequência destas ideias da sua juventude estudantil, mas prenunciando já alguma viragem, o artigo "Toque de Clarim», publicado em 4 de setembro de 1941 no periódico Acção. Semanário da Vida Portuguesa ${ }^{(18)}$, dirigido por Manuel Múrias, gerou, segundo o seu próprio testemunho ${ }^{(19)}$, algum eco entre os intelectuais católicos, que o incitou a que saísse da sua terra natal, onde deveria exercer a advocacia, em direção a Lisboa e ao jornalismo.

Não se afastava do que escrevera nos Estudos, mas alertava de forma enérgica para a necessidade de criar mentores que orientariam a juventude, a qual ansiava por um mundo novo, por uma «nova forma de vida», no contexto de uma «revolução», "personalista comunitária», oposta ao «Velho Mundo, individualista e liberal». Curiosamente, afirmava que esses novos mentores nacionalistas e católicos deveriam afastar-se do «ensaio histórico» que caracterizara a forma de escrever dos nacionalistas e católicos do passado: «Impõe-se a criação de editoriais que actualizem o pensamento nacionalista. Mas, por Deus!, escolhamse colaboradores que, se forem historiógrafos, não escrevam História».

E, anunciando a necessidade de novas ideias católicas, terminava: «Só assim corresponderemos ao voto mais íntimo da era presente e ao apelo angustiado do Papa - que pede 'uma Cristandade modelo e guia para este Mundo profundamente enfermo'».

Pouco se alterava, a não ser o tom do discurso, e, assim, segundo Amândio César ${ }^{(20)}$, conhecido combatente nacionalista, fora este artigo que levara à formação do grupo dos «Amigos de Braga», onde pontificou o mestre da polémica e da direita portuguesas, Alfredo Pimenta, que Silva Dias seguira mas em relação ao qual se iria afastar, assim como relativamente ao nacionalista referido, seu conterrâneo e, sensivelmente, da sua geração ${ }^{(21)}$.

(17) «Um século decadente», Estudos, 17 (187) (1940), p. 220-230.

(18) Artigo e jornal cits., p. 1 e 7.

(19) Curriculum Vitae, 1969, p. 6.

(20) «Os 'Amigos de Braga' de Alfredo Pimenta», Boletim de Trabalhos Históricos, 33 (1982).

(21) Amândio César (1921, Arcos de Valdevez - 1987, Lisboa), crítico literário, ficcionista e poeta, ideólogo nacionalista, seria um dos defensores mais denodados do «Ultramar Português», em diversas obras publicadas aquando da «Guerra Colonial». 
Neste contexto de «novidade», os livros, opúsculos e artigos seguintes abordam questões de espiritualidade e de sociologia católicas ${ }^{(22)}$, ou de defesa de uma posição católica de «Europa» ${ }^{(23)}$ - que teve como textos de referência os escritos de Gonzague de Reynold ${ }^{(24)}$ - e de crítica à conceção de intelectuais como Abel Salazar ${ }^{(25)}$, ou de compilação de textos de escritores tradicionalistas católicos, como o teólogo tomista do século XIX Jaime Balmes ${ }^{(26)}$ e Ramiro de Maeztu, que saiu do republicanismo e do socialismo e que acabou por ser assassinado no início da Guerra Civil de Espanha ${ }^{(27)}$, ou ainda de introdução e notas a importantes escritos, como o do Cardeal Mercier, neo-tomista, defensor de uma reforma da Igreja e opositor à invasão da Bélgica por Hitler ${ }^{(28)}$, e do Cardeal Emmanuel Suhard, arcebispo de Paris durante a invasão alemã e o governo de Vichy ${ }^{(29)}$. E é então, nos inícios dos anos 40 , que se inicia a sua intervenção regular no diário católico Novidades, a que veio a acrescentar também artigos para outro jornal católico, $A V o z^{(30)}$. Escreverá nestes periódicos, especialmente no primeiro, dezenas de $\operatorname{artigos}^{(31)}$.

Pode dizer-se, pois, que Silva Dias se encontrava - polemicamente, é certo, como muitos outros, e sem praticamente citar Salazar e sem quase se referir ao Estado Novo - num círculo que enquadrava (ou não punha

(22) Recorde-se, por exemplo, os livros e opúsculos Escândalo da Verdade, Leiria, Edições Juventude, 1943, Humanismo social. Problemas da propriedade e do trabalho, Lisboa, União Gráfica, 1949, Trabalho e Propriedade, Lisboa, União Gráfica, 1950, e Responsabilidades sociais, Lisboa Oficinas Gráficas Casa Portuguesa, 1952, e os artigos «Acção Católica e cultura católica», Primeira Decenal da Acção Católica Portuguesa, Coimbra, 1946, vol. 2, p. 95-149, e «O cristão na encruzilhada», Estudos, 28 (290) (1950), pp. 449-465, 28 (291) (1950), p. 499-508, e 28 (292) (1950), p. 563-571. Pode acrescentar-se a comunicação «Mariologia e sociologia», apresentada no Congresso Mariano de Évora de 1946 (16 a 18 de outubro). De resto, alguns dos textos citados foram apresentados em outros encontros católicos e depois publicados.

(23) O Problema da Europa, Lisboa, Edições Gama, 1945.

(24) Ver, sobretudo, L'Europe tragique. La Révolution moderne, la fin d'un monde, Paris Éditions Spes, 1935.

(25) A Crise da Europa, Lisboa, Cosmos, 1942.

(26) Balmes. Cem páginas. Selec., trad. e pref. de J. S. da Silva Dias. Lisboa, Bertrand, 1945.

(27) Maeztu. Cem páginas. Selec. e pref. de J. S. da Silva Dias. Lisboa, Bertrand, 1948.

(28) Código social de Malines, Lisboa, Pro Domo, 1945.

(29) Primavera ou decadência da Igreja? Pastoral do Cardeal Suhard, Lisboa, 1947.

(30) Ver alguns títulos, do jornal Novidades e de $A$ Voz (de 1942 a 1964), in Revista de História das Ideias, 8, «Colaboração na imprensa», p. 17-19.

(31) Ver os seus títulos em Maria do Rosário Azenha, http:/ / www.ci.uc.pt/ihti/ portugues/ihti/silva_dias.html, p. 2-7. 
em causa) o regime nesses anos 40 e 50, como comprovam também outros escritos compilados em livros, como é o caso dos seus Estudos Políticos, obra publicada na católica editora Casa do Castelo, de Coimbra, em 1947, onde defendia uma Democracia Cristã, contra o Comunismo e o Fascismo, que considerava (como era comum também entre autores de conceção socialista) como a mais recente encarnação política do poder burguês ${ }^{(32)}$.

$\mathrm{O}$ artigo em que regressa aos Estudos da sua juventude estudantil, «O cristão na encruzilhada», publicado em 1950 (tinha só cerca de 34 anos), é bem revelador dessa evolução na continuidade.

Então, ainda ocupa um lugar fundamental no seu pensamento cristão - marcado pela influência de Maritain (sobre o qual escreveu vários artigos no Novidades) - o anticomunismo, considerando a ideologia soviética uma «contra-Igreja». Por sua vez também fala da existência de um «desvio progressista» católico, que pensava tornar-se perigoso pelo facto de, por influência de Marx, poder cair numa conceção materialista. Um dos seus erros seria pensar que a fé e as virtudes cristãs floresceriam «automaticamente como vegetação espontânea numa sociedade liberta de pesadelos capitalistas». Assim, o cristianismo social de Silva Dias seria ao mesmo tempo anticomunista e anticapitalista, supondo que os cristãos, para o serem, pertencendo à Igreja, teriam «o direito de julgamento moral último dos costumes políticos e sociais não enquanto políticos mas enquanto costumes». E, nesta encruzilhada, por vezes pouco clara e até ambígua, voltavase também Silva Dias contra os «conservadores vulgares», contra o «desvio integralista» (dirá mais tarde «integrista», na sua análise histórica), contra o «clericalismo», contra os «nacionalistas integrais». Era assim que defendia uma política que teria necessária conexão com a moral: «A frente moral e a frente política são solidárias. A eficácia temporal não vai sem a eficácia eterna e vice-versa».

Daí, pois, a sua teoria cristã social, que, nesses anos, se afastava do conservadorismo, mas não se aproximava também do progressismo. Por isso, se não mostrava ligação ao regime de Salazar, não se opunha a ele.

Nessa altura, de resto, desempenhava em Lisboa funções que não o podiam separar do Estado Novo, como assistente dos Serviços de Ação

(32) Estudos Políticos, Coimbra, Casa do Castelo, 1948. Curiosamente o exemplar que tenho deste livro contém uma dedicatória pessoal ao Padre Moreira das Neves, biógrafo do Cardeal Patriarca e que foi chefe de Redação do jornal Novidades. 
Social do Instituto Nacional de Trabalho e Previdência (1942-1946), secretário do Tribunal de Execução de Penas (1949-1953), inspetor da Polícia Judiciária (1953-1956), diretor do Instituto de Assistência a Menores (1956) e provedor da Casa Pia (1956-1958). Se abordou, devido à sua formação e por via desses lugares que ocupou, algumas posições sociais mais avançadas, isso não era anormal no contexto político de então, em que a questão social fazia parte da ideologia corporativista. Recorde-se o caso do Padre Abel Varzim - ligado ao jornal O Trabalhador, que Silva Dias terá ajudado a fundar ${ }^{(33)}$, e às organizações católicas do operariado - que, depois de ter sido deputado da União Nacional (de 1938 a 1942), manifestou, no seu caso claramente, posições contra o Estado Novo. Algo idêntico sucedeu também, por exemplo, com Sedas Nunes, que pertenceu ao Gabinete de Estudos Corporativos e que veio a ser a grande referência do Gabinete de Estudos Sociais (GIS), que originaria em 1974 o Instituto de Ciências Sociais ${ }^{(34)}$. «Estado Social» será, por outro lado, o nome que Marcelo Caetano - com quem Silva Dias não simpatizava - dará ao «Estado Novo», tanto quanto possível como substituição ou modernização do conceito usado no fim da Ditadura Militar e de invenção fascista italiana (Stato nuovo) $)^{(35)}$.

\section{História... Que História?}

Peço licença para usar o título de um dos meus últimos livros ${ }^{(36)}-$ onde abordo o meu modo de pensar a História, de que sou devedor (com várias inflexões pessoais) ao meu Mestre - para refletir, à maneira de introdução ao próximo ponto, sobre o que pensava ou que ia pensando Silva Dias sobre a História.

(33) Ver Silva Dias, Curriculum Vitae..., cit., p. 6.

(34) Ver A. Sedas Nunes, «Histórias, uma história e a História - sobre as origens das modernas Ciências Sociais em Portugal», Análise Social, n. ${ }^{\circ}$ 100, terceira série, XXIV (1998), $1 .^{\circ}$, p. $11-55$.

(35) Ver o nosso texto Marcello Caetano, Marcelismo e «Estado Social», Coimbra, Imprensa da Universidade, 2013. Sobre o conceito de Stato nuovo no radicalismo nacionalista e no fascismo italiano, ver Giovanni Gentile, Il mito dello Stato nuovo. Dal radicalismo nazionale al Fascismo, Bari, Laterza, 1999.

(36) História... Que História? Notas críticas de um historiador, Lisboa, Temas e Debates/ Círculo de Leitores, 2015. 
Embora com palavras hoje diferentes e, mesmo nesse tempo, ambíguas, talvez se possa captar o seu pensamento já nos inícios dos anos 40 no livro, já citado, em que reflete sobre o «rumo da Juventude», editado numa editora católica de Leiria apelidada exatamente «Edições Juventude» - a obra tem o título, já de si polémico, Escândalo da Verdade ${ }^{(37)}$.

Ultrapassando as teses já genericamente referidas, de uma conceção de vida e de conhecimento de tipo católico social (o qual tanto poderia surgir na monarquia, como no regime republicano), opondo-se ao que considerava «heresias modernas», como o comunismo, o totalitarismo (sobre que disserta abundantemente), o nacionalismo, o liberalismo...(38), vejamos apenas o que nos diz sobre a História, no subtítulo que intitula «História e historicismo» ${ }^{(39)}$.

Os principais autores criticados são dois dos nomes de ensaístas de História de ideologia integralista (diferentes, todavia): João Ameal (historiador do regime salazarista ${ }^{(40)}$, mas também autor de um livro precisamente intitulado Rumo da Juventude $\left.{ }^{(41)}\right)$, e Alfredo Pimenta, num livro intitulado Novos Estudos Filosóficos e Críticos ${ }^{(42)}$.

Segundo Silva Dias, ainda que João Ameal tenha distinguido o que considerou «história-morta» e «história-viva» e aceitasse que esta fosse realizada, entendia-a, assim como (de outro modo) a de Oliveira Martins, como uma «história apologética», caracterizada por um «finalismo teleológico». Para ele, se, na qualidade de pensador católico, julgava que «o homem só pode ser explicado pela Teologia, no domínio da ciência revelada», defendia também que na área das "ciências culturais» só poderia ser explicado pela «antropologia filosófica». Se discutia o que considerava a falsa interpretação dos «jacobinos liberais», também afirmava que não se poderia cair num erro idêntico, mas ao contrário, ou seja, no que chama «sectarismo azul». Nesta medida, o historiador não

(37) Escândalo da Verdade, Leiria, Edições Juventude, 1943.

(38) Ver Escândalo da Verdade..., cit., sobretudo o título «Sentido do Totalitarismo», que termina com o subtítulo «Heresias Modernas», p. 65 ss.

(39) Este subtítulo (p. 130-138) faz parte de um título chamado «O rumo da Juventude» (p. 129 ss.).

(40) Recorde-se que Ameal foi o autor da História de Portugal (Porto, Livraria Tavares Martins, 1940), que obteve o prémio Alexandre Herculano, do Secretariado de Propaganda Nacional.

(41) Rumo da Juventude, Lisboa, Editorial Acção, 1942.

(42) Novos Estudos Filosóficos e Críticos, Lisboa, Imprensa Nacional, 1935. 
poderia partir de «preconceitos», mas precisava sim de se «apetrechar, não só com o conhecimento das ciências auxiliares da história, mas também com boa formação filosófica, social e política». Com isto - e tendo como apoio a posição manifestada pelo historiador alemão, perseguido pelo nazismo, Enst Bernheim, numa edição espanhola, intitulada Introdución al Estudio de la Historia (1939)(43) - defendia Silva Dias que o historiador filósofo é fundamental para o conhecimento, considerando que a história, para ser entendida na sua complexidade, tem de supor uma ampla preparação nesse domínio da reflexão filosófica. Parecendo entrar em contradição com a crítica a Ameal e preparando já a sua reflexão sobre Pimenta, Silva Dias concluía: «A história pela história representa uma atitude tão absurda como a da arte pela arte. A ciência como tudo o que é humano, tem uma função finalista».

Mas isso não queria dizer que o historiador se devesse envolver apenas no domínio da filosofia, que se tratava de um terreno movediço. E, assim, concluía: «Antes de tentar qualquer filosofia da história importa fazer história 'tout-court'. Só a partir deste trabalho ainda incipiente em Portugal ${ }^{(44)}$, é possível ensaiar a elaboração fecunda de uma filosofia».

Por outro lado, Silva Dias critica o que chama o «historicismo», palavra que não coincide no seu significado com o termo usado mais tarde no conhecido e polémico livro de Karl Popper, que sempre por ele haveria de ser citado, The proverty of the historicism (1961), que procurava atacar as filosofias da História ou uma espécie de sociologia historicista, de tipo holístico, nomeadamente o marxismo entendido como sistema de interpretação da História.

Para ele o historicismo era outra coisa, era a «arqueologia da história», a «história objetiva» (de que falava Alfredo Pimenta) conceito que pode também e deve ter outro sentido -, a história confundida com erudição. E, traduzindo para português, citava René Marans (um adepto de Maurras), num volume coordenado por Pierre Lasserre (que cortou com o maurrasianismo, para ser essencialmente crítico literário, professor e diretor da École Pratiques des Hautes Études) intitulado La doctrine officielle de L'Université (1912):

(43) Introducción al estudio de la historia, Barcelona, Labor, 1937.

(44) Cita, a este propósito Herculano, Gama Barros, Martins Sarmento, Alberto Sampaio, Costa Lobo, Caetano do Amaral... 
Daríamos ideia muito justa da História, dizendo que ela repousa na confusão da erudição com a história. Obra de homens que não possuem as grandes qualidades do historiador, que não têm tão pouco a modéstia e a dignidade severa do erudito, mas que querem ser, ao mesmo tempo, uma e outra coisa sem distinguirem, nem sequer hierarquizarem o que cumpre a um e a outro, ela torna-se a ruína da verdadeira erudição como da verdadeira história.

E completava Silva Dias esta citação: «Por deformação mental o historicista não possui capacidade de compreender, como o historiador, nem de fantasiar e integrar, como o filósofo. Vê apenas factos e datas a averiguar».

Desta forma, o crítico deste tipo de «historicismo» ataca esta propensão, de «miopia intelectual», só para ver o «factozinho». Para Silva Dias, o «historicismo» era, pois, o que se veio a chamar "factualismo" ou mesmo, de forma menos correta, o «positivismo» historiográfico.

Ultrapassando Alfredo Pimenta, que passou, na sua vida polémica, pelas ideologias mais variadas e terminou numa conceção de radicalismo nacionalista, mas que foi também um erudito de arquivos (chegou a diretor da Torre do Tombo) com uma certa tendência para uma história que considerava ao mesmo tempo objetiva e subjetiva e passando, de novo, a João Ameal, Silva Dias que, nessa altura, ainda estava sobretudo interessado no «rumo da juventude», terminava outra vez com uma reflexão crítica sobre o autor neo-integralista: «Não recusamos a ninguém o direito de praticar a história-morta ou a história-viva. Negamos somente que à história pertença o exclusivo das ciências culturais e que o seu estudo seja o mais urgente nesta hora» ${ }^{(45)}$.

Estávamos, porém, nos anos 40 e Silva Dias - periodista e escrevendo ainda no tempo em que era sobretudo jornalista católico («num livro escrito à banca da redação de um diário», nos «poucos momentos livres deixados por uma vida profissional absorvente» $\left.{ }^{(46)}\right)$ e que não abandonara por completo o integralismo, um certo pensamento «integralista» - ainda não se tornara historiador, o que só deveria suceder no final da década e no início dos anos 50. Então será historiador, sem nunca abandonar a reflexão sobre os vários problemas da sociedade. Falará sempre da necessidade de

(45) Cf. Escândalo da Verdade..., cit., p.130-138.

(46) Escândalo da Verdade..., cit., Advertência, p. 5. 
o historiador desenvolver a sua cultura em várias áreas. Daí a sua troca de palavras, preferindo o conceito de «historiosofia» ao de «historiografia».

Nos anos 60, o Doutor José Sebastião da Silva Dias, já na Universidade, passará então a refletir de outro modo e sobre outras experiências filosóficas e sociológicas. Como dirá numa entrevista de modo mais ou menos informal, num passo já transcrito por António Resende de Oliveira:

Durante os anos sessenta andei às voltas com as leituras marxianas de Gramsci e Lukacs. Descobri, em simultâneo, a escola de Francfort. Acima de tudo, reflecti intensamente sobre a minha experiência e consciência do real histórico e na possibilidade de acesso dos saberes culturais à qualificação das ciências rigorosas. E assim, lenta mas progressivamente, avancei para a conclusão de que o conhecer compreensivo-comunicativo, a que os «cientistas» do sector empírico-analítico chamavam as «ciências do paleio», estava de facto a converter-se num conhecimento científico ${ }^{(47)}$.

$\mathrm{Na}$ verdade, eram essas conceções filosóficas marxianas de que constantemente nos falava, o que não o impedia que atacasse as conceções marxistas ortodoxas, por vezes de forma exagerada e ilusória, como sucedeu em provas públicas com a minha dissertação de doutoramento, assim como não impedia que viessem ao de cimo, no seu modo de ser, algumas formas de estar «catedráticas». Igualmente estavam nele sempre presentes, embora de forma crítica, as teorias e as práticas do grupo dos Annales e da «Nouvelle Histoire». Mas o que importa é que fomos seus discípulos no modo como aprendemos, de uma maneira ou de outra (e por vezes de forma bem independente), a «fazer história», enquanto, como diretor da linha 1 do Centro de História da Sociedade e da Cultura, assistíamos a vários seminários em que convidava professores estrangeiros, nomeadamente de França e de Espanha.

Não deixava mesmo de se afastar das suas correntes sociais-católicas, a que nos referimos: mantinha a sua linha socialista, mas agora seguia numa via de esquerda. Assim, em 1980 escrevia um artigo para O Jornal intitulado

(47) António Resende de Oliveira, texto citado na Revista de História das Ideias, 1986, p. 598. A entrevista de Silva Dias (esta entre outras concedidas a jornais) foi publicada com o seguinte título «Questões sobre a Cultura Portuguesa. Responde o Prof. Dr. José Sebastião da Silva Dias», ICALP. Revista, ago. / dez, n. ${ }^{{ }^{\mathrm{s}}}$ 2-3, (1985), p. 45-57. Foi depois transcrita numa coletânea de textos com objetivos pedagógicos publicada na Universidade de Évora: $A$ Cultura em Portugal: História e teoria (...) (Para uso dos alunos), Évora, 1993. p. 245 
«Ser cristão e ser de esquerda» e, entre os intelectuais que nos visitaram, contou-se, por exemplo, José Luís Arangúren, um dos mais acutilantes escritores da causa católica progressista da Península Ibérica, que, todavia, fizera a sua caminhada a partir do franquismo ${ }^{(48)}$. Afinal confirmava-se a sua ação agora decididamente progressista, manifestada desde os inícios dos anos 70, numa carta dirigida ao bispo de Porto, D. António Ferreira Gomes. Ali prometia a sua ida ao Porto para assistir a uma conferência do conhecido padre Yves Congar, conhecido eclesiólogo e ecumenista, e propunha a sua intervenção num colóquio a realizar na mesma cidade. Este encontro realizou-se, na verdade, na Torre da Marca, com a presença do prelado e de políticos liberais, como o professor da Faculdade de Medicina da Universidade do Porto Joaquim Pinto Machado, em que estive também presente, como simples assistente, bem como outros seus discípulos, e onde apresentou uma comunicação sobre temas de história religiosa ${ }^{(49)}$.

A História de Silva Dias assentava, com efeito, fundamentalmente, no estudo das correntes culturais, e nomeadamente das correntes culturais de espiritualidade, fossem elas quais fossem. Só daí passou para as questões da «razão política», que foram sempre marginais no seu estudo, até porque a sua inabilidade para «fazer política», e até para estabelecer relações cordiais (embora a sua ética de lealdade viesse normalmente ao de cimo), se tornou sempre evidente.

\section{A investigação da modernidade e dos inícios da contemporaneidade como meio de modernização do conhecimento e do pensamento}

Silva Dias entrou para a Faculdade de Letras da Universidade de Coimbra em 1957-1958 para reger a cadeira de História da Cultura

(48) Dele foi traduzida para português uma das suas obras fundamentais: A Crise do Catolicismo, Coimbra, Almedina, 1971.

(49) Ver a referida carta ao bispo de Porto, datada de 29 de agosto de 1970, em Arquivos Nacionais/Torre do Tombo, PIDE/DGS, José Sebastião da Silva Dias, processo CI (2) 6718, NT 7459. Nessa carta propunha-se, na verdade, estar presente em setembro seguinte na conferência do Padre Congar e participar num colóquio, que, com efeito, se realizou em data que não consigo precisar, onde desejava apresentar uma comunicação que estivesse de acordo com a as «limitações e compromissos de homem de ciência», citando três hipóteses temáticas: as «incidências do inquisitorialismo dos católicos e não-católicos portugueses até aos nossos dias»; a «fé e tipicidade das estruturas históricas do catolicismo português; e os 'mal-entendidos' de dois séculos de mentalidade católica portuguesa: 1770-1970». 
Portuguesa, que fazia parte do plano de estudos da reforma das Faculdades de Letras que surgiu precisamente nesse ano de $1957^{(50)}$. Ainda por essa altura, o Conselho Escolar encarregou-o de reger a cadeira de História da Filosofia em Portugal. Veio a suceder, na prática, ao conhecido pensador e historiador da filosofia e das ideias e defensor de princípios liberais, republicano e de oposição ao Estado Novo, Joaquim de Carvalho (1892-1958), administrador da Imprensa da Universidade de Coimbra, quando ela foi extinta por Salazar em 1934, e que faleceria em 27 de outubro de 1958, precisamente no início do ano escolar. No ano seguinte, em 1958, foi encarregado também da docência da disciplina de História da Cultura Moderna (note-se que, na legislação não se falava em «História da Cultura Contemporânea»).

Na verdade, é aqui que se inicia, no domínio da investigação e do ensino da História das Ideias, a fase mais interessante de Silva Dias do ponto de vista científico, embora as suas origens estejam no seu primeiro livro, resultante das suas pesquisas realizadas em Lisboa: a obra incompleta (como seria próprio do estilo do investigador, que prometia sempre mais um volume ou outra obra, que por vezes não chegavam a ser editados) e já referida, Portugal e a cultura europeia. Sécs. XVI a XVIII, publicada em 1952.

Através dos temas abordados ao longo dos anos, como os referentes às correntes de espiritualidade $\mathrm{e}^{(51)}$, em que se releva as posições erasmianas, à Inquisição e à Censura e às suas vítimas ${ }^{(52)}$, à política cultural da época de D. João III ${ }^{(53)}$, freada nas suas posições mais avançadas pelo conservadorismo, e mesmo aos Descobrimentos ${ }^{(54)}$, tomava historiograficamente - ou «historisoficamente», como gostava

(50) Decreto n. ${ }^{\circ}$ 41.341, de 30 de outubro de 1957 (Diário do Governo, I série, da mesma data).

(51) Correntes do sentimento religioso em Portugal (séculos XVI a XVIII), tomo I, 2 vols., Coimbra, Instituto de Estudos Filosóficos, 1960.

(52) Por exemplo, «Seiscentismo e renovação em Portugal no século XVIII. Estudo de um processo inquisitorial», Biblos, 36 (1960), p. 201-264, «O primeiro rol de livros proibidos», Biblos, 39, (1963), p. 231-327, e «Frei Valentim da Luz e os conflitos ideológicos do século XVI», Biblos, 43 (1967), p. 409-709.

(53) A política cultural da época de D. João III, 2 vols., Coimbra, Instituto de Estudos Filosóficos, 1969.

(54) Os Descobrimentos e a problemática cultural do século XVI, Coimbra, Seminário de Cultura Portuguesa, 1973. Seguiram-se outras edições (a 3. a surgiu em Lisboa através da Presença, em 1988). 
de dizer - uma posição mais avançada. Recorde-se que esses temas eram abordados por uma história oficial, e mesmo académica, de uma forma ideológica conservadora. Ou seja, enquanto as correntes institucionais da Igreja portuguesa, desde Manuel Gonçalves Cerejeira, e mesmo antes, tentavam mostrar que o Santo Ofício, apesar da sua crueldade, havia concorrido para a unidade católica de Portugal (posição que, como vimos, Silva Dias não enjeitou como ideólogo católico), e os Descobrimentos, sobretudo durante a Guerra Colonial, eram considerados como a grande gesta de Portugal uno, pluricontinental e plurirracial, Silva Dias - como, no que diz respeito à «Expansão», Vitorino Magalhães Godinho, numa perspetiva de História Económica -, tentava analisar, no domínio da História das Ideias, os temas numa perspetiva de investigação objetiva mas interpretativa. Desta forma, indiretamente, fazia-se uma crítica ao «sistema», que impossibilitava alterações de fundo na política salazarista de educação, ao mesmo tempo que se mostrava que a Universidade estava essencialmente à margem do desenvolvimento científico e técnico no tempo dos «Descobrimentos».

Mas nos anos 60, Silva Dias - que se ligava ao Instituto de Filosofia da Faculdade de Letras e lecionava algumas cadeiras de História da Cultura que se designavam por "não agrupadas" - só ligeiramente se aproximava, como investigador, do século XVIII, considerado um tempo renovador, devido às práticas reformistas do Marquês de Pombal e do Iluminismo, que não era abordado nas cadeiras de História, com grande angústia dos estudantes. No domínio da sua pesquisa, só nos anos 70, em certos casos já depois do 25 de Abril de 1974 e na década de 80, em Coimbra e em Lisboa, na Universidade Nova, mergulhará nalguns temas setecentistas ${ }^{(55)}$, bem como nas temáticas gerais do século XIX, neste caso geralmente em curtas, mas incisivas, comunicações em congressos, que começaram então a organizar-se ${ }^{(56)}$.

(55) «O eclectismo em Portugal no século XVIII (Génese de uma atitude filosófica)», Revista Portuguesa de Pedagogia, 6 (1972), p. 3-24; «Avanço cultural e avanço maçónico na segunda metade do século XVIII», Revista de História das Ideias, I (1977), p. 395-417; com a sua esposa, Graça Silva Dias, Os primórdios da Maçonaria em Portugal, 2 vols. em 4 tomos, Lisboa, INIC, 1980; «Pombalismo e teoria política», Cultura. História, Filosofia, 1, 1982, p. 45-114; e «Pombalismo e projecto político», Cultura. História, Filosofia, 2 (1983), p. 185-318, e 3 (1984), p. 27-151.

(56) Individualismo e racionalismo em Portugal (1840-1870), Coimbra, Seminário de Cultura Portuguesa, 1973; «O Vintismo: realidades e estrangulamentos políticos», Análise Social, 16 (61/62) (1980), p. 273-278, e «A revolução liberal portuguesa: amálgama e não 
Será, no entanto, como orientador de seminários do fim da licenciatura que, já nos anos 60 - fiz parte do seu primeiro seminário, em 1964-1965, e até do seu pré-seminário, de 1963-1964 (o que constituiu uma inovação) -, levará os seus alunos a tratar de temas quase tabu na Universidade portuguesa, como eram o Liberalismo e a Contrarrevolução tradicionalista e absolutista, ao mesmo tempo que fazia novas experiências pedagógicas e, por vezes de forma polémica, fazia implodir uma crítica cerrada ao ensino que se verificava na Universidade. Neste caso, salvo raras exceções, pouco se relacionava com Veiga Simão (que, contraditoriamente, nos atraía em certos casos com algumas reformas e nos afastava com outras medidas), assim como - conforme disse - não gostava de Marcello e da sua pseudo e ilusória «Primavera», por motivos de sensibilidade e também por verificar ali ambiguidades insanáveis.

O certo, porém, é que foram o marcelismo, as reformas de Veiga Simão, a nova orientação dos antigos órgãos de apoio à pesquisa (como o Instituto de Alta Cultura) e até as novas reitorias universitárias, como a de José Gouveia Monteiro na Universidade de Coimbra (1970-1971), que possibilitaram algumas alterações institucionais e talvez mesmo a publicação dessas teses de licenciatura sobre o século XIX, que foram editadas nos anos 70, no âmbito do que chamou «Seminário da Cultura Portuguesa» ${ }^{(57)}$.

Disse já que tenho a honra de ter sido um dos primeiros discípulos de Silva Dias. Com ele, e com Albert Silbert em França, e os seus discípulos, bem como com autores mais ou menos marginais, como Joel Serrão, José Tengarrinha ou Costa Dias, inicia-se praticamente o estudo da História Contemporânea em Portugal, ao contrário do que se apregoa por vezes,

substituição de classes», in Miriam Halpern Pereira, O liberalismo na Península Ibérica na primeira metade do século XIX, Lisboa, Sá da Costa, 1981, vol. I, p. 21-25.

(57) Recordem-se algumas dessas publicações, integradas no projeto sobre «História das Ideias em Portugal nos séculos XVIII e XIX», do Instituto de Alta Cultura, e apoiadas por ele e pela Direção-Geral do Ensino Superior: Luís Reis Torgal, Tradicionalismo e Contra Revolução. O pensamento e a acção de José da Gama e Castro, Coimbra, Seminário de Cultura Portuguesa, 1973 (tese de licenciatura apresentada em 1966, policop., com o título José da Gama e Castro. História do seu pensamento político); José Eduardo Horta Correia, Liberalismo e Catolicismo. O problema congreganista, Coimbra, Seminário de Cultura Portuguesa, 1974; José Esteves Pereira, Silvestre Pinheiro Ferreira. O seu pensamento político, Coimbra, Seminário de Cultura Portuguesa, 1974. Além destas obras publicadas (as primeiras), provenientes de teses de licenciatura, muitas outras foram apresentadas como dissertações policopiadas, antes e depois do 25 de Abril. Depois sucedeu-se a edição de teses de vários dos seus discípulos de História Contemporânea, que constituíram uma verdadeira «escola». 
quando se esquece o passado da historiografia e se olha sobretudo para a atualidade dos últimos anos, num lamentável presentismo.

As várias alterações curriculares das Faculdades de Letras e de Ciências Sociais e Humanas, desde as autorreformas de 1974-1975 à reforma global de Sottomayor Cardia (ainda parente de Silva Dias, que com ele colaborou), de $1978^{(58)}$, alteraram os objetivos do então criado Instituto de História e Teoria das Ideias. Em Coimbra as cadeiras de História da Cultura passaram a ligar-se ao curso de História e, com a reforma Cardia, esse Instituto passaria a lecionar História Cultural e das Mentalidades (conceito trazido de alguns historiadores franceses da Nouvelle Histoire, que se propunham abordar o tema complexo das Mentalidades), desde a Idade Média e da Época Moderna ao Mundo Contemporâneo, o que fez alargar o leque temporal da investigação, criando mesmo potencialidades para se chegar - como sucedeu - à história do mundo contemporâneo mais recente.

\section{A ideia de uma Universidade modernizada}

Como se viu sucintamente, e como se concluirá com este ponto, Silva Dias integrou-se na vida das universidades onde ensinou e investigou, e da sociedade em geral, ainda que nem sempre com grande sucesso do ponto de vista, por assim dizer, «político», ao invés do que se passou no campo científico. As suas propostas eram geralmente precursoras e avançadas, mas nem sempre eram assumidas de modo cordial e formalmente correto, sobretudo num tempo em que tudo se decidia num espaço de elite magistral, autoritário e secreto, e, noutro tempo,

(58) Decreto n. ${ }^{\circ}$ 53/78, de 31 de maio. Apesar de os dois primeiros estudos que se vão referir visarem apenas o período anterior ao 25 de Abril e o ensino da Idade Média e o terceiro a História Económica tal como foi lecionada em Coimbra até 1974, têm interesse os trabalhos de Armando Luís Carvalho Homem, «Saber positivo e teorização nos primitivos currículos da licenciatura em História (1957 e 1958)», História. Revista da FLUP, IV série, 1 (2011), p. 23-27, e «A Idade Média nas Universidades portuguesas (1911-1987). Legislação, ensino, investigação», História. Revista da FLUP, (1992), p. 351-361, e João Paulo Avelãs Nunes, A História Económica e Social na Faculdade de Letras da Universidade de Coimbra (19111974), Lisboa, Instituto de Inovação Educacional, 1995. Importa também citar, com um carácter mais abrangente a obra de Luís Reis Torgal, José Maria Amado Mendes e Fernando Catroga, História da História em Portugal. Séculos XIX-XX, Lisboa, Círculo de Leitores, 1996 (2. ${ }^{a}$ ed.: 2 vols., Lisboa, Temas e Debates, 1998). 
depois do 25 de Abril, em que fluía o movimento de reformas demasiado idealistas e, em certos casos, estereotipadas ou oportunistas. Mas, além disso, Silva Dias era uma personalidade difícil, colocada num ambiente difícil, a Universidade. As suas críticas ao que chamou o «simonismo» (com referência a Veiga Simão) ou o «neo-simonismo», assim como à «cartilha marxista-leninista» - por mais razão que tivesse -, deixavam marcas indeléveis. Destaque-se, nesse contexto, a breve passagem - no ano de 1974-1975 - pelo Conselho Diretivo da Faculdade de Letras da Universidade de Coimbra, bem como alguns conflitos que acabou por ter em Coimbra e em Lisboa.

Deve, porém, dizer-se - como se pode supor pelo que se referiu e se poderá antever de seguida - que as suas posições em política de ensino ou mesmo em política geral, independentemente da sua discutível forma pessoal, eram, em muitos casos, reveladoras de grande clarividência e atualidade, como por exemplo quando se referia à ideia de uma sociedade política «aberta», falando de uma das conhecidas obras de Karl Popper, e se opunha, citando Jacques Julliard, a uma «política profissional» ${ }^{(59)}$.

A sua bibliografia sobre as universidades e o ensino datam de longe. No diário católico Novidades, escrevia, já em 1944, sobre «Universidade e Ensino» ${ }^{(60)}$ e, em 1946, sobre as universidades católicas ${ }^{(61)}$, que começavam a mover os militantes, numa lógica diferente daquela que hoje move, porque o que estava acima de tudo em causa não era o sucesso escolar e profissional (quase diríamos empresarial), mas sim a formação de uma cultura e de uma espiritualidade católicas. Recorde-se que, de Braga, surgiria, no início dos anos 50, uma reivindicação repassada de conservadorismo católico ${ }^{(62)}$, e movimentos mais evoluídos corporizados pela Juventude Universitária Católica (JUC) lutavam pela formação de uma verdadeira e polimorfa cultura cristã ${ }^{(63)}$. Ao mesmo tempo, iam

(59) Ver Karl Popper, The open society and its enemies, Londres, G. Routledges \& Sons, 1945 e Jacques Julliard, Contre la politique profissionelle, Paris, Éditions du Seuil, 1977. Ver, de Silva Dias, o artigo infra-citado sobre a FRS (nota 69). De Popper cita uma edição dos anos 70 .

(60) «Universidade e Ensino», Novidades, 1 jan. 1944.

(61) «Universidades católicas», Novidades, 8 set. 1946.

(62) Fernando de Aguiar, Por uma Universidade Católica. Uma Campanha do Espírito, Braga, Sigma Editora, 1951. O livro é constituído por artigos publicados no Correio do Minho em 1950-1951.

(63) O pensamento católico e a Universidade. $1^{\circ}$ Congresso Nacional da Juventude Universitária Católica. Lisboa, 1953. 
surgindo livros sobre a crise da Universidade e nem sempre vindos da oposição democrática.

Mais tarde, em 1971, Silva Dias escrevia para a revista católica Brotéria, dois longos artigos sobre a Universidade. Em 1973, em artigos para os jornais, um, de grande significado, que nascera nesse ano, o Expresso, e outro que era o símbolo da oposição, República, dirigido então por Raul Rego, mação e ex-seminarista, falava, respetivamente, sobre a reforma do sistema educativo ${ }^{(64)}$ e sobre a anulação curricular das dissertações de licenciatura ${ }^{(65)}$, o que pareceria contraditório com a sua orientação. Só não o era porque, na prática, muitos alunos não cumpriam essa unidade curricular que lhes concederia o grau de «licenciados» e apenas concorriam ao ensino como «bacharéis», e porque Silva Dias há muito que defendia a continuidade da investigação pelos alunos com maiores aptidões, em cursos de pós-graduação.

Os textos sobre a Universidade e sobre o sistema de Ensino sucedemse depois do 25 de Abril de 1974, em artigos distribuídos por vários periódicos, quase todos hoje desaparecidos, mas que constituíam então jornais nacionais de grande impacto: Diário de Lisboa, A Capital, A Luta, Expresso, Diário de Notícias, Portugal Hoje, O Jornal... ${ }^{(66)}$ Mais do que referir, em primeiro lugar, a temática dos artigos, quis salientar o seu labor diverso, a fim de confirmar a capacidade de intervenção pública de Silva Dias. Até porque, mutatis mutandis, os seus escritos não se distinguiam muito no seu espírito, nestes anos instáveis de 70 e 80 do século passado, embora as circunstâncias se fossem alterando. No meio das suas angústias - «o melhor é tratarmos do nosso jardim», dizia aos seus discípulos nos momentos mais pessimistas -, ia esperando que as «ciências humanas» provocassem

(64) «A reforma do sistema educativo», Expresso, 31 mar. 1973.

(65) «O problema das dissertações de licenciatura», República, 27 jul. 1973.

(66) «A reforma e as reformas na Universidade», Diário de Lisboa, 2 jul. 1974; «Políticas de educação», A Capital, 3 dez. 1974; «Quem acode ao ensino secundário?», A Capital, 26 jul. 1976; «A inércia dos MEIC's provisórios», A Luta, 8 jul. 1976; «As universidades regionais», A Luta, 9 jul. 1976; «A escola portuguesa à deriva», A Capital, 20 jul. 1976; «A Universidade que temos, a Universidade que queremos», Expresso, 3 set. 1976; «O obscurantismo à espreita da Universidade», O Jornal, 3 set. 1976; «Uma Universidade competente, uma Universidade eficiente», Expresso, 9 set. 1976; «Universidade, pluralismo, modernidade», Diário de Notícias, 18 nov. 1980; «Que ensino superior I? Universidade e cultura. Regime de austeridade, mas não de pobreza», e "Que ensino superior II? Democracia na Universidade: em defesa do diálogo e da participação», Portugal Hoje, 26 e 27 maio 1981; «Da carreira universitária à carreira da Universidade», O Jornal, 28 maio 1981; «Uma Universidade para o Portugal de hoje», Diário de Notícias, 17 jun. 1981. 
desenvolvimento ${ }^{(67)}$ (e falava dos sintomas da crise da cultura dos últimos $\left.\operatorname{anos}^{(68)}\right)$, ao contrário do que muitas vezes se dizia e hoje ainda mais se diz ou se pensa mesmo sem o dizer. E também ia assumindo as suas posições políticas, por vezes com algum caráter polémico, como quando se referia aos conceitos de social-democracia e de socialismo democrático ou dava a sua opinião sobre o aparecimento da Frente Republicana e Socialista $\left(\right.$ FRS ${ }^{(69)}$. Neste caso, contra a corrente e contra o sentido meramente conjuntural dessa coligação, mas com certa coerência, afirmava, depois de combater o que chamava a «vulgata marxista-leninista», apelando para a atualização da reflexão sobre o socialismo, que a FRS seria a prefiguração de um compromisso histórico necessário entre o Partido Socialista, o Partido Comunista Português e o Partido Social Democrata ${ }^{(70)}$.

De resto, desde o artigo da Brotéria (recorde-se: do início do marcelismo, 1971), Silva Dias defendia posições em tudo idênticas ao seus amigos Miller Guerra ${ }^{(71)}$ e Joaquim Pinto Machado, respetivamente das Faculdades de Medicina de Lisboa e do Porto, que se batiam na «ala liberal» da Assembleia Nacional, e seguia as reflexões que na França eram feitas por Edgar Faure ${ }^{(72)}$, ao mesmo tempo que se aproximava dos colegas que defendiam na Universidade e na Faculdade de Letras conceções de esquerda ou, pelo menos, de reformismo ${ }^{(73)}$, afastando-se, por outro lado, do setor mais à direita. Opunha-se - já então - a uma falsa

(67) «Ciências humanas e desenvolvimento», O Jornal, 12 jun. 1981.

(68) «Sintomas de crise na cultura dos últimos cinco anos», Diário de Notícias, 10 maio 1979

(69) «Preconceito e social-democracia», O Jornal, 12-19 jun. 1980, p. 30; «FRS é prefiguração do compromisso histórico. Entrevista polémica do professor Silva Dias», Portugal Hoje, 22 jul. 1980, p. 3-4.

(70) A FRS, registada em Agosto de 1980, foi uma coligação conjuntural de partidos com fins eleitorais, que se extinguiu dois anos depois, formada pelo PS, pela União de Esquerda Socialista Democrática (UEDS) e a Acção Democrática Independente (ASDI), em oposição à coligação de centro-direita (Aliança Democrática. AD).

(71) Além das intervenções parlamentares de Miller Guerra e contendo a sua essência, ver a obra, citada por Silva Dias, As Universidades Tradicionais e a Sociedade Moderna, Lisboa, Moraes Editores, 1970.

(72) Philosophie d'une réforme, Paris, Plon, 1969. Faure fora ministre de l'Éducation Nationale de 12 de julho de 1968 a 20 de junho de 1969.

(73) Recordo sempre as relações, nem sempre concordantes, que teve com colegas que pertenciam ao sector católico social, social-democrata, genericamente aos meios democráticos ou que se colocavam mesmo mais à esquerda. Entre eles, poderia citar Carlos Mota Pinto, António Barbosa de Melo, Victor de Matos, Miguel Baptista Pereira, Joaquim Ferreira Gomes, Graciano de Oliveira... 
ideia de desenvolvimento integrada exclusivamente na «problemática do capitalismo fabril e tecnocrático». Assim afirma:

E não parece que a renovação deva processar-se - pelo menos que deva processar-se simplesmente - à luz da problemática sócio-económica do capitalismo fabril e tecnocrático. Seria a modelação da universidade pelos critérios de uma certa teoria do desenvolvimento. Esgotava os seus objectivos nos de uma escola sem rosto humano: uma escola para a investigação científico-natural e tecnológica e para a formação de tecnocratas integrados na realidade social existente ${ }^{(74)}$.

A reforma da Universidade teria, pois, de ser «solidária» com a reforma da sociedade - uma não poderia viver sem a outra -, assim como a reforma da Universidade teria de ser «solidária» com a reforma do Ensino em geral ${ }^{(75)}$. E essa reforma não deveria ser apenas curricular (com novos planos de estudos, com a possibilidade de o aluno frequentar disciplinas diversas, com diferenças entre a preparação no bacharelato e na licenciatura, com a criação de cursos de pós-graduação...), mas abranger todas as áreas: a autonomia e a gestão (retomando e recriando órgãos de gestão central, com professores e estudantes, e dando maior autonomia aos Grupos e não apenas às Faculdades), a qualidade dos professores e da sua carreira, as práticas pedagógicas, etc. E Silva Dias apresentava propostas concretas sobre o documento ministerial do início desse ano de 1971, intitulado Linhas gerais da reforma do Ensino Superior ${ }^{(76)}$.

Concluindo: o meu objetivo não foi entrar no âmago das reformas de ensino apresentadas por Silva Dias, mas mostrar como esteve desde o início - sobretudo desde que se começaram a agitar as águas na Universidade, acompanhando o movimento estudantil (que considerava, em parte, uma consequência do estado de crise da Universidade e da sociedade) - ao lado das reformas mais arrojadas. Reformas já «velhas», dado que desde há muito se falava de «reformas», nomeadamente em períodos de crise (o final da Monarquia e o início da República, os anos 30 e 40 do século XX, os anos 60, já com outras dimensões)? Mas mesmo

(74) Artigos citados, analisados pela separata da Brotéria, intitulada A reforma da Universidade e os seus problemas, Lisboa, 1971, p. 14-15.

(75) Cf. A reforma da Universidade..., cit., p. 16-17.

(76) Linhas Gerais da Reforma do Ensino Superior, Lisboa, Ministério da Educação Nacional, Janeiro de 1971. 
assim reformas sempre novas, mesmo hoje em que a Universidade, apesar dos seus desenvolvimentos, tem criado uma burocracia que mata as inovações pedagógicas e científicas, o sentido democrático da gestão e em que a massificação do ensino e o desemprego jovem têm enfermado as potencialidades de verdadeiras reformas, que se devem integrar num mundo ecuménico e não num «mundo plano», pautado pela força do capital. A universidade e o ensino, como a sociedade, são como uma espiral, que por vezes parecem voltar atrás. Criticá-las - mesmo sabendo que nos restam pouco mais do que as utopias - foi uma das lições que Silva Dias me deu, mesmo que muitas vezes com ele tivesse estado em desacordo. Por isso também me perguntei num dos últimos livros escrito com um colega brasileiro: Que universidade? ${ }^{(77)}$.

\section{Silva Dias, a Censura e a PIDE/DGS}

Pouco ainda se sabe da Censura, nomeadamente aos livros, pensandose, pela prática política e cultural que se conhece, que ela se exerceria mais posteriormente à publicação do que previamente, como sucedia com as publicações periódicas. Mas não seria assim de todo, especialmente quando as editoras ou os autores enviavam os manuscritos à Censura para exercer a sua função, o que só sucedia em situação excecional.

No caso de Silva Dias, conhece-se a censura feita à obra Escândalo da Verdade (1943), acabada de se imprimir em 2 de junho de 1943, tendo o Relatório da Censura o despacho «Autorizado», com a data de 21 de julho do mesmo ano. O censor era um militar, como sucedia em muitos casos - o major Ávila Madruga. O que nos diz era bem simples e expectável.

Ali se afirma que Silva Dias combatia pelas «novas idéias [sic] sociais-cristãs», demonstrava uma «vasta erudição filosófica» e focava «com rudeza a crise social, política e moral do Mundo», revelando-se um «doutrinário audaz da política da Acção católica». Nesse sentido, fazia «afirmações arrojadas que poderia [sic] ser interpretadas por extremistas, a não ser encarada a sua tese como um estudo filosófico, baseado num socialismo cristão inspirado na 'Rerum Novarum' de

(77) Que Universidade? Interrogações sobre os caminhos da Universidade em Portugal e no Brasil, em co-autoria com Angelo Brigato Ésther, Juiz de Fora, Studio Editora UFJF, 2013. Edição em Portugal: Coimbra, Imprensa da Universidade, 2014. 
Leão XIII e encíclicas de Pio XI». Místico cristão e defensor da doutrina social da Igreja, fora elogiado, no jornal Novidades (27.6.1943), pelo padre Moreira das Neves. Nota, finalmente, que na última parte do livro Silva Dias refutava afirmações de João Ameal e de Alfredo Pimenta, neste último caso, relativamente à sua ligação do catolicismo à posição político-monárquica. Ou seja, o censor não deixava de notar que o autor considerava, ao contrário de Pimenta, que a Igreja não condenava as instituições republicanas, proclamando que ela deveria «fugir da tentação» de estar «ao serviço da monarquia».

O major Ávila Madruga concluía com estas palavras: «Apesar da crueza de algumas afirmações do autor, do seu entusiasmo socialista e da maneira como encara os problemas sociais (sempre com uma base evangélica), não considero de proibir a sua obra, não achando inconveniente a publicação deste livro» ${ }^{(78)}$.

Quanto à ação da PIDE (Polícia Internacional e de Defesa do Estado), pode dizer-se que Silva Dias quase não foi vigiado por ela. Foi sim pela DGS (Direcção Geral de Segurança) em que Marcelo Caetano converteu, em 1969(79), a polícia política, em uma das suas várias operações de cosmética. Compreende-se os motivos, dado que - conforme vimos a sua posição ideológica manteve-se essencialmente numa linha católica social, que nem sequer assumia um carácter progressista, até aos anos 60. De resto, foi essa a posição sempre manifestada por Silva Dias e por si afirmada, como se pode ver, de uma forma sintomática num dos primeiros documentos apreendidos pela DGS e cuja cópia se encontra no seu processo dos Serviços Centrais.

Trata-se de uma carta enviada da sua casa da Figueira de Foz, datada de 29 de agosto de 1970, ao bispo do Porto, D. António Ferreira Gomes ${ }^{(80)}$. Nela

(78) Despacho dos Serviços da Censura de 21/7/1943, tendo como base o Relatório n..$^{\circ} 2795$, assinado por Ávila Madruga, maj.[major]. Este Relatório foi dado a conhecer por António Tavares Proença, nas suas pesquisas para a tese de mestrado A Censura durante o "Estado Novo" e a sua execução à Imprensa Periódica na Região Tradicional, Histórica e Cultural da Beira Baixa, segundo os documentos existentes na Censura, Lisboa, Universidade Nova de Lisboa, Mestrado em História Cultural e Política, [1992].

(79) Decreto-lei n. ${ }^{\circ} 49.401$, de 24 novembro de 1969.

(80) Ver a referida carta ao bispo de Porto, datada de 29 de agosto de 1970, em Arquivos Nacionais / Torre do Tombo, PIDE/DGS, José Sebastião da Silva Dias, Serviços Centrais, processo SC/CI (2) 6718, NT 7459, carta que foi enviada ao Director Geral de Segurança - Serviços Centrais, em Lisboa, por Armindo Ferreira da Silva, da Delegação de Coimbra, em 31 de agosto de 1970. 
louva o prelado ex-exilado, que Marcello, no ano anterior, no âmbito da sua efémera «Primavera», autorizara o regresso do estrangeiro, de onde fora obrigado a não voltar desde que em Julho de 1959 saíra da sua diocese para umas férias forçadas em Espanha, depois de ter sido publicitada a sua famosa «carta» ou «pró-memória» a Salazar, de 13 de julho de 1958. Depois de louvar o «ato de coragem» de D. António, «indispensável e oportuno, do ponto de vista do Evangelho e da História», ao denunciar o «inquisitorialismo»-além de estar presente no seu espírito a citada «carta», falava expressamente da «prisão do Abade da Lixa» ${ }^{(81)}$-, afirmava mesmo que os «modos de ver» de ambos confluíam «nas questões essenciais». Assim, propunha-se deixar o seu «exílio» para com ele colaborar, na condição de cientista: «exílio voluntário em que vivo há cerca de um vinténio», acentuava.

Antes dessa epístola apenas encontramos: a cópia de uma carta, um pouco hermética e reveladora de algumas «entrelinhas», datada de 22 de setembro de 1966 (ainda vigorava a PIDE), do escritor brasileiro e militante católico social-democrata Alceu Amoroso Lima, para a Professora Maria de Lourdes Belchior Pontes, da Faculdade de Letras de Lisboa e ligada ao movimento católico, que envia cumprimentos ao «querido e saudoso amigo José Sebastião da Silva Dias» ${ }^{(82)}$; uma notícia das provas de Silva Dias para professor agregado, sem qualquer comentário da polícia, extraída do Diário de Coimbra de 13 de dezembro de $1969^{(83)}$; e um esclarecimento de Silva Dias no jornal A Capital, de 10 de outubro de 1969, dirigido a Amândio César, a corrigir uma afirmação sua de que, entre os nomes dos potenciais candidatos das «listas independentes», pelos «nacionalistas», estaria ele, considerando «insidiosa» essa informação, que não tinha nenhuma «verosimilhança» ${ }^{(84)}$.

(81) Padre Mário de Oliveira, que fora pároco de Macieira da Lixa (Felgueiras), cujos sermões teriam sido denunciados à DGS devido à sua crítica à «Guerra Colonial», que continuaram as práticas nas missas por ele rezadas em Mansoa, na Guiné, a que tive ocasião de assistir. Note-se que D. António Ferreira Gomes esteve presente no julgamento político do Padre Mário de Oliveira, realizado em 7 e 8 de janeiro de 1971. Ver sobre o tema o livro do advogado do Padre Mário de Oliveira, José da Silva, Subversão ou evangelho?, Porto, 1971.

(82) Ver a citada carta no referido processo SC/CI (2) 6718, NT 7459.

(83) Ver Arquivos Nacionais/Torre do Tombo, PIDE/DGS, José Sebastião da Silva Dias, Delegação de Coimbra, processo 41516, NT 4916.

(84) Ver o artigo «Um esclarecimento do Professor José Sebastião da Silva Dias» em A Capital, de 10/10/1969, no qual se opõe à citada afirmação de Amândio César, contida num artigo publicado anteriormente, intitulado «Nomes conhecidos nos meios políticos formam as lista dos nacionalistas independentes». Ver o citado processo SC/CI (2) 6718, NT 7459. 
A partir da carta ao bispo de Porto sucedem-se as informações sobre Silva Dias, tendo como fundamento razões mais ou menos significativas ou insignificantes (mas significantes para uma polícia que queria tudo saber): a presença (como outros colegas) nas conferências de Eduardo Lourenço, sobre o tema «Centenário da Geração de 1870», em abril de $1971^{(85)}$; um cartão dirigido ao Professor Luís Filipe Lindley Cintra, da oposição democrática, a pedir uma entrevista, de janeiro de 1972 ${ }^{(86)}$; a resposta de Francisco Sá Carneiro, de 2 de fevereiro de 1973, à manifestação de solidariedade que lhe enviara Silva Dias (em 17 de novembro de 1972), juntando ainda o documento de renúncia do mandato de deputado à Assembleia Nacional, datado de 25 de janeiro de 1973( ${ }^{(87)}$; uma carta, de maio de 1973, ao ministro da Educação Nacional, Veiga Simão, sobre as eventuais mudanças de direção da Faculdade de Letras da Universidade de Coimbra ${ }^{(88)}$; a cópia do voto de Silva Dias, apresentado no Conselho Escolar de 22 de maio de 1973, sobre «O problema da dissertação de Licenciatura nas Faculdades de Letras», que foi publicado (como se viu) no jornal República e que lhe trouxe grandes complicações (mesmo a ameaça de um processo disciplinar) devido ao carácter secreto das suas sessões ${ }^{(89)}$. Sobretudo depois da prisão do seu filho, José Vicente, em abril de 1972, a vigilância de Silva Dias e de sua Esposa, Graça Silva Dias, ia-se tornando permanente. Era feita em relação à sua residência, como às saídas do seu automóvel Peugeot 403, como aos seus passeios e encontros em cafés ou por altura de manifestações de apoio aos estudantes em luta ou mesmo de afirmações de Silva Dias contra o Governo ${ }^{(90)}$.

(85) As conferências realizaram-se em 16 de abril de 1971 (Informação de 21 de abril) numa das salas da Fundação Gulbenkian, e no Teatro Académico Gil Vicente de Coimbra, em 18 do mesmo mês, tendo assistido (segundo informação da DGS), à primeira, os professores Paulo Quintela, Orlando de Carvalho, Victor de Matos, Américo da Costa Ramalho e José Sebastião da Silva Dias, e, à segunda, Orlando de Carvalho, Víctor de Matos e Silva Dias. Ver processo 41516, NT 4916.

(86) Pocesso SC/CI (2) 6718, NT 7459.

(87) Ver processo cit.

(88) Ver processo cit... O envio dessa carta pelo inspetor-adjunto Armindo Ferreira da Silva, da Delegação da DGS de Coimbra, ao Diretor Geral, datada de 7 de maio de 1973, já refere o que se verá a seguir, ou seja, que o autor da carta era «pai de José Vicente de Sousa da Silva Dias, que se encontra a cumprir pena de prisão por atividades subversivas».

(89) Ver processo cit..

(90) Ver em especial o processo citado da Delegação de Coimbra da DGS 41516, NT 4916. As vigilâncias verificavam-se por acção da DGS, mas também da Polícia de 
Como se vê, Silva Dias acabou por ser constantemente vigiado e só o 25 de Abril de 1974 terminou com a prisão do seu filho e com a sua luta contra o sistema, sem, todavia, se ter integrado propriamente num grupo específico de oposição. Daí que a revolução o levasse quase de imediato à direção da Faculdade de Letras, onde esteve por breves meses, depois de algumas desilusões quanto à possibilidade de subir a voos maiores de ordem política.

\section{A concluir}

Deixei aqui, neste ano do centenário do nascimento de José Sebastião da Silva Dias, não mais do que um esboço, continuando, e quiçá aprofundando, outros esboços, mais formais, que anteriormente foram produzidos - um esboço que poderá ser um ponto de partida para um livro que a sua complexa personalidade justificava. Como se viu, não me limitei a um simples panegírico, não omitindo alguns aspetos mais polémicos de Silva Dias. «Fazer História» significa, como nos ensinava o nosso mestre, analisar criticamente o objeto que nos é apresentado, reinterpretando-o sempre, à medida que o vamos «lendo», com base em outras fontes que vamos encontrando e utilizando novos conhecimentos que vamos adquirindo. Mas fica a ideia - assim o espero - que poucos mestres como Silva Dias tiveram uma vida tão intensa e criativa, nos seus vários aspetos, ideológicos, científicos, pedagógicos e institucionais. Acima de tudo com todas as ambiguidades e contradições que lhe encontremos - o que não se pode esquecer é que foi um homem de intervenção permanente. Esta é a faceta mais interessante de Silva Dias, que acabou por morrer perturbado com o que conseguiu realizar, mas sobretudo com o que não conseguiu concretizar. E foi muito. E hoje estaria uma vez mais em debate sobre a Ciência que se faz e em relação às instituições existentes. Estaria sempre a favor das «Ciências Humanas» ou «Sociais» (questionando os seus resultados) e, em especial, da História, como estaria lutando por uma nova Universidade e por uma nova Sociedade...

Segurança Pública (PSP). Numa dada altura, em 18 de outubro de 1972, Silva Dias lera na rua um panfleto dos estudantes (onde se podia ler «Unamos a nossa luta à dos estudantes de Lisboa. Reunião hoje à 1.30 horas todos no átrio das cantinas») e rasgara-o, perante a vigilância de um sub-chefe da PSP, que o identificara. Silva Dias terá então gritado: «Se quiserem prendam-me. Já lá tenho um filho!...». 